\title{
The Relationship between Gastroesofageal Reflux and Pneumonia in Children
}

1 Danijela Vrankić

2 Biserka Sedić

2 Ana Marija Hošnjak

3 Tomislav Salaj

${ }^{1}$ Children's Hospital Srebrnjak, Zagreb, Croatia

2 University of Applied Health Sciences, Department of Nursing, Zagreb, Croatia

${ }^{3}$ University Hospital Centre Zagreb, Zagreb, Croatia

Article received: 04.06.2018.

Article accepted: 20.09.2018.

Author for correspondence:

Danijela Vrankić

Children's Hospital Srebrnjak

Srebrnjak 100, Zagreb, Croatia

Phone: + 385919105783

E-mail: d.vrankic.tm@gmail.com

DOI: $10.24141 / 2 / 2 / 2 / 4$

Keywords: gastroesophageal reflux, aspiration pneumonia, impedance

\section{Abstract}

Introduction. Gastroesophageal reflux is the return of the gastric contents into the upper parts of the gastrointestinal tract, and they often enter into the respiratory system resulting in chronic respiratory symptoms and illnesses. Aspiration pneumonia in particular is caused by gastroesophageal reflux. Gastroesophageal reflux is diagnosed using a multichannel intraluminal impedance with $\mathrm{pH}$-metry while pneumonia is diagnosed radiologically. By analysing the findings the patient is diagnosed with aspiration pneumonia.

Aim. To investigate the presence of aspiration pneumonia caused by gastroesophageal reflux by comparing the findings of a multichannel intraluminal impedance with pneumonia radiological findings.

Methods. The study was conducted at the Department of Pulmonology and Allergology for Preschool and Schoolchildren at the Children's Hospital Srebrnjak in the early 2017 by a nurse working at the department. The sample consists of 100 children admitted to hospital for chronic respiratory symptoms who underwent a multichannel intraluminal impedance with $\mathrm{pH}$-metry in order to prove the existence of gastroesophageal reflux and who had a chest X-ray.

Results. The pathologic gastroesophageal reflux was observed in 81 children (81\%), a normal chest $X$-ray in 81 children (81\%), and 19 children (19\%) had pathological findings of chest X-ray, out of which 8 children had pneumonia (42.1\%).

Discussion. In a study of 100 children with chronic respiratory symptoms without risk factors that would favor the aspiration of gastric contents, 7 children with aspiration pneumonia caused by gastroesophageal reflux were identified.

Conclusion. The obtained results show a significant presence of aspiration pneumonia in children with chronic respiratory symptoms which confirms the need for active testing for gastroesophageal reflux in patients with respiratory symptoms, with the purpose of conducting adequate reflux treatment and treatment of pneumonia. 


\section{Introduction}

Gastroesophageal reflux disease (GERD) refers to the return of gastric contents into the esophagus (1). In infancy, it is a physiological manifestation occurring in $100 \%$ of children under 3 years of age and does not cause any significant symptoms (2). Pathologic reflux (3) is the return of gastric contents with symptoms in the gastrointestinal tract called gastroesophageal reflux disease (GERD) $(1,2)$. Symptoms and illnesses caused by GERD include spitting up, vomiting, not gaining body mass, increased salivation, chest pain, heartburn, burping, nausea, difficulty swallowing, blood in the stool, anemia, irritability and neck extension (Sandifer syndrome).

The return of gastric contents into the respiratory system leads to laryngopharyngeal reflux (LPR) $(4,5)$ and aspiration syndromes (6). Aspiration syndromes lead to a number of respiratory symptoms and illnesses (6). Symptoms and illnesses caused by LPR are apnea, hoarseness, throat clearing, postnasal secretion, cough, throat pain, burning mouth, laryngitis, bronchospasm, sinusitis and middle ear inflammation. Long-lasting microaspirations of the gastric content into the lungs can cause chronic bronchitis, bronchiectasis, pulmonary fibrosis and pneumonia $(4,5,7)$.

Pneumonia occurs in about $50 \%$ of children with aspiration of the gastric content (6), and may be acute, recurrent or nonresolving pneumonia (5). They are caused by the penetration of digestive tract bacteria into the respiratory system which has already been damaged by the action of gastric contents, and most commonly affect the right lung and lower lobes (6, 8). Risk factors such as enteral nutrition through gastric probe, diaphragmatic hernia surgery, neurological disorders with difficulty chewing and swallowing, vocal cords paralysis, tracheoesophageal fistula, laryngeal and phyryngeal cleft, and cleft palate and lip stimulate aspiration $(5,6)$.

Children with respiratory symptoms are treated at the Children's Hospital Srebrnjak, where children with chronic respiratory symptoms require additional treatment, which involves using a 24-hour multichannel intraluminal impedance-pH metry (MII / $\mathrm{pH})$ for measuring the return of gastric contents $(9,10)$ and radiological treatment, for the purpose of diagnosing gastroesophageal reflux and its effect on the symptoms in the respiratory tract $(11,12)$.

\section{Nurse's intervention in placing a probe for multichannel intraluminal impedance with 24 hour ph-metry}

The use of multichannel intraluminal impedance with 24-hour $\mathrm{pH}$-metry improved the diagnosis of gastroesophageal reflux and aspiration pneumonia and became an indispensable part of treatment of chronic and recurrent respiratory problems. The role of a nurse in correctly placing the probe and the correct diagnosis of the disorder is very important.

The procedure of placing a probe is standardized and requires the child's hospitalization (13). Prior to the hospitalization, the nurse informs the parent or the guardian of the child that the day before and during the measurement they must not take oral therapy and that they must come on an empty stomach. During the hospital treatment, the child is taken to the department and the parents sign the consent form for the procedure that the nurse checks prior to the procedure. Upon admission of the child, the nurse takes relevant medical history about the acute medical condition of the child to exclude respiratory or gastrointestinal infections because the child must be afebrile, healthy and on an empty stomach.

The nurse identifies possible allergies, and the reasons and chronic symptoms for which the child is being treated. It is important that the nurse always asks about the previous chest $\mathrm{X}$-rays and when they were performed, in order to avoid frequent and excessive radiation of the child. In the case of a child being $\mathrm{x}$-rayed on multiple occasions or immediately before the treatment, the physician decide not to use $x$-rays to check the position of the probe. In these cases, the probe position is estimated by an approximate calculation based on the height of the child and the $\mathrm{pH}$ values obtained when placing the probe.

The probe used for the multichannel intraluminal impedance with $\mathrm{pH}$-metry must be stored in a dry place, the probe is clean but not sterile and should not be used more than once because the reuse of a disposable probe can lead to cross contamination and patient infection. Prior to the placing, the nurse takes the probe out of its packaging and checks whether the probe is intact or damaged. After inspecting the probe, the nurse calibrates the probe, ie. the electrodes on the probe. The calibration of the probe is carried out in several stages:

1. The probe electrodes are placed in a liquid for 15 minutes. The liquid must have a $\mathrm{pH}$ of 7 , and 
the physiological solution is most often used. All eight probe electrodes must be immersed in the appropriate liquid during calibration. A new calibration liquid is required for each patient.

2. After 15 minutes the probe is rinsed under water and dried.

3. The probe is then plugged into the measuring device and the probe calibration program is started by pressing the calibration key on the device. Every new measurement requires new batteries to be used in the measuring device in order to prevent accidental shutdown and the interruption of the scan.

4. The probe is first put into the acidic liquid with a $\mathrm{pH}$ of 4.

5. After the completion of the calibration, the probe is washed with water and dried.

6. The probe is placed in a liquid with a $\mathrm{pH}$ of 7.

7. When the device shows "record" it is ready for probe placement and the start of the measurement.

At the end of the electrode calibration, the nurse prepares a card for entering the measured values. The card is placed in the computer, and the nurse enters in the appropriate program the patient information - the patient's identification number, name and surname, date of birth, body mass and height, and code and number of the probe. Upon completion, the card is removed from the computer and placed in the measuring device. The nurse determines the length of the probe that needs to be placed according to the physician's instructions using the modified Strobel formula: the height of the child/ 4 minus $2 \mathrm{~cm}$. The obtained length is marked on the probe. This makes the measuring device and probe ready for placement.

When placing the probe, the child is sitting in the mother's lap or in the lap of the medical staff, or if calm, on its own. The nurse patiently and calmly explains the procedure of placing the probe. Prior to placing the probe into the nose, the nurse examines the contraindications for the introduction of probe, which include the more severe deviation of the septum, nasal congestion or nosebleed. In these cases, the placing of the probe is left to the physician or an ORL specialist. In the case of the impossibility of pulling the probe through the nasal passage an ORL physician places the probe while using the endoscope. The top of the probe is covered with lidocaine for easier and painless sliding of the probe.
The probe is placed through the nose along the lower part of the nasal passage, while the child drinks water using the straw to facilitate swallowing and entering of the probe into the esophagus. The probe is placed through the nose till the marked length obtained by the formula calculation. A nurse, with or without spatula, checks the position of the probe in the throat, ie whether the probe passed through the nasal passage since there is a possibility of bending and stopping of the probe in the nose passage. Attention should also be given to the dry cough that indicates to the position of the probe in the trachea or one of the major bronchi. Once the probe position is checked, the probe is fixed to the cheek, pulled over the ear and further fixed to the neck. The position of the probe is checked by a physician on a chest X-ray and if necessary, the nurse corrects the position of the probe according to the $\mathrm{X}$-ray finding and the doctor's instructions. This is how the probe placement is completed.

After the probe position is checked, the device is turned on and the monitoring starts. The monitoring lasts for 24 hours, it can last shorter but not less than 18 hours. During the monitoring, the patient, the parent or the guardian will keep a journal of food and fluid intake, changes in the body position, activities performed by the child, and possible symptoms of heartburn, coughing and vomiting. The device has the appropriate keys for standing and lying positions, for the start and end of food intake, and for the occurence of cough, pain, and heartburn symptoms.

At the end of the monitoring, the nurse presses the stop key to stop the monitoring and pulls out and takes care of the probe. This is where the nurse's job finishes. The card is removed from the device and placed in the memory stick of the computer and the doctor reads the findings.

The psychological preparation of the child by parents and nurses is an essential component to make the procedure as successful as possible with the least trauma for the child. The nurse explains the procedure to the parents and the child prior to the hospitalization in detail and in the way that the child could understand it as well. In such a way, the parent, who is familiar with the procedure, can reduce the child's fear of upcoming hospitalization at home. Upon the child's admission to hospital, the nurse again calmly and kindly explains to the child all the procedures that are being carried out, and in the same manner conducts the probe placement. Parents' stay with the 
child before, during and after the procedure lessens the child's fear and sense of unease.

The role of a nurse is important at all stages of the procedure: during the patient's preparation for the procedure, during and after the procedure. Care for the patient during the procedure requires a multidisciplinary and professional level of nursing knowledge.

Aim

The aim of the paper was to investigate the presence of aspiration pneumonia in children with chronic respiratory symptoms caused by reflux. In children treated for chronic respiratory symptoms without risk factors for aspiration development, the results obtained by $\mathrm{MII} / \mathrm{pH}$ and chest X-ray were compared and thus establishing the correlation between the pathologic gastroesophageal reflux findings and with pneumonia radiological findings.

In this way, in the study group, the frequency of aspiration pneumonia caused by GER was assessed in children without risk factors for aspiration.

\section{Methods}

The research was conducted at the Department of Pulmonology and Allergology for Preschool and Schoolchildren at the Children's Hospital Srebrnjak, at the beginning of 2017. A retrospective analysis of the children's data from 2016 and a prospective analysis of children's data from 2017 research were conducted. The research was carried out by a nurse responsible for the $\mathrm{MII} / \mathrm{pH}$ probe placement in the abovestated department.

The data of 100 children hospitalized due to the treatment of chronic or recurrent respiratory symptoms were analysed. There were 69 boys (69\%) and 31 girls (31\%). The average age was 9.18 years, and the age range from 13 months to 18 years. The research did not include children with neurological risk factors and anatomic anomalies that may favor the development of aspiration syndromes. Furthermore, they were healthy children, i.e. children with no febrile or acute symptoms of respiratory or digestive infections, as these are contraindicated symptoms for $\mathrm{MII} / \mathrm{pH}$. All children involved in the study had a signed parents' consent for the procedure.

As part of the treatment, a multichannel intraluminal impedance with 24-hour pH-metry was performed, alongside a usual chest $X$-ray. The purpose of chest $X$-ray is to confirm the appropriate position of the probe, but also to get insight into the condition of the lungs, which is necessary in view of the chronic respiratory symptoms. Due to $\mathrm{X}$-ray induced radiation, there is always a tendency to combine these two procedures so as to perform one chest $X$-ray for lung diagnostics and to confirm the position of the $\mathrm{MII} / \mathrm{pH}$ probe.

The results of the multichannel intraluminal impedance with 24-hour pH-metry, is analyzed and read by a departmental physician. In the study, multichannel intraluminal impedance with $\mathrm{pH}$-metry findings were processed and classified as:

1. Normal MII/pH - if negative or borderline without the need for medication.

2. Pathologic gastroesophageal reflux - if positive and with the necessity for medication.

Chest $X$-ray findings, described by a radiologist specialist, are processed and classified as:

1. Normal chest X-ray.

2. Pathological finding that includes changes described as endobronchitis, peribronchitis and inflammatory infiltration.

Pathological radiological findings are also divided by the place of pathological change:

\section{Right lung \\ 2. Left lung \\ 3. Both lungs}

After the analysis and the processing of the required data, the statistical analysis of the results using a chi-squared test was performed, and the results were presented either in tables or graphs. 


\section{Results}

Out of 100 children, the physician read pathologic gastroesophageal reflux in 81 children (81\%), while 19 children (19\%) had normal values of the multichannel intraluminal impedance with $\mathrm{pH}$-metry (Graph 1). The average age among children with pathologic GER in our study is 9.49 compared to children with normal values of multichannel intraluminal impedance whose average age is 7.84 years.

Out of 100 children who had a chest X-ray, 81 children (81\%) had a normal X-ray and 19 children (19\%) had pathological findings of the $X$-ray. Endobronchitis was present in $4(21.05 \%)$, peribronchitis in 7 (36.84\%), and inflammation in 8 children (42.1\%). The place of pathological changes is located in the right lung in 11 children (57.89\%), in the left lung in one child $(5.26 \%)$, and in both lungs in two children (36.84\%) (Graph 2).

Table 1 shows the correlation of GER findings with chest X-ray findings. Among 81 children with proven pathologic GER, 16 children have pathological findings of chest X-ray - $11.11 \%$ have endobronchitis or peri-

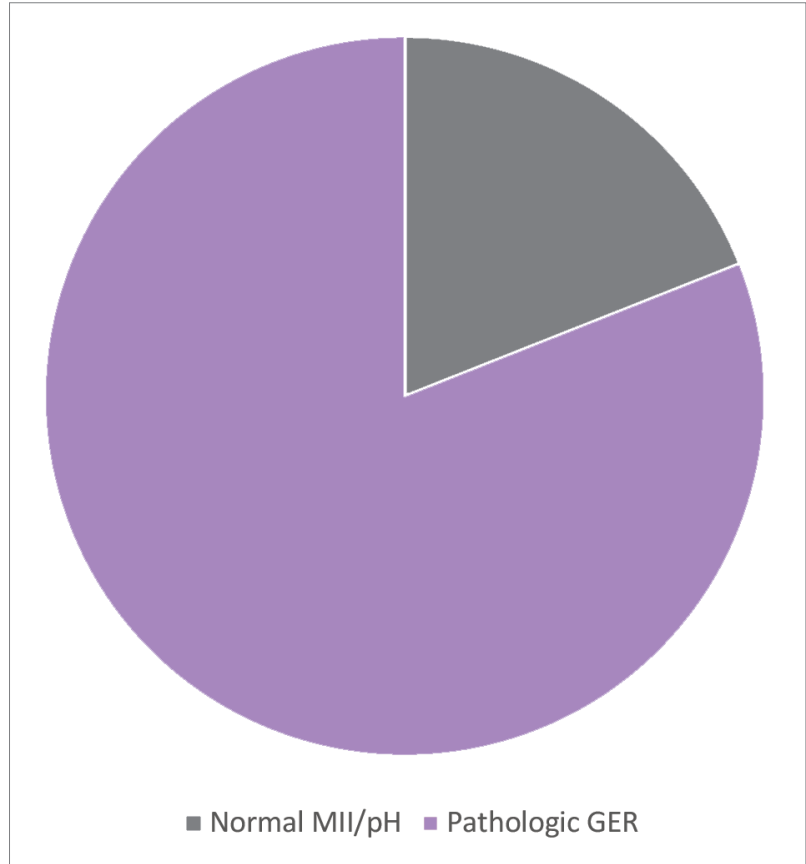

\section{Graph 1. Results of MII/pH-metry in $\mathbf{1 0 0}$ study} children

bronchitis, and $8.64 \%$ of children have pneumonia. Out of 19 children with normal MII/pH values, three children had a pathological finding of chest X-ray (15.78\%).

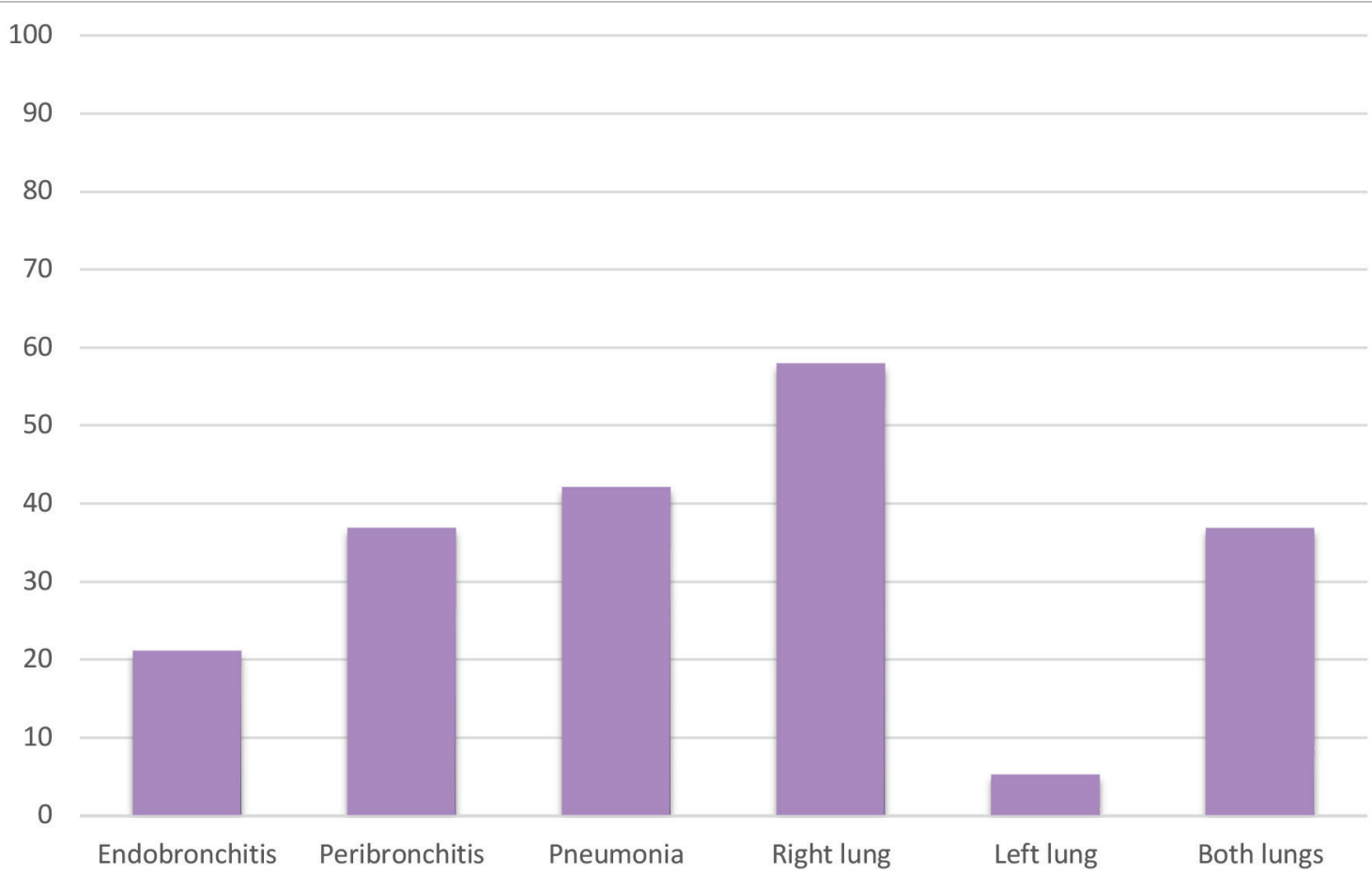




\section{Table 1. Distribution of pathologic GER findings with pathological findings of chest X-ray}

$\begin{array}{ccc}\text { Chest X-ray findings } & \text { Pathologic GER } & \text { Normal MII/pH } \\ \mathbf{8 1} \text { children } & \mathbf{1 9} \text { children } \\ \text { Normal } & 65 \text { children } & 16 \text { children } \\ 81 \text { children } & 80.24 \% & 84.21 \% \\ \text { Endobronchitis or peribronchitis } & 9 \text { children } & 2 \text { children } \\ 11 \text { children } & 11.11 \% & 10.52 \% \\ \text { Pneumonia } & 7 \text { children } & 1 \text { child } \\ 8 \text { children } & 8.64 \% & 5.26 \%\end{array}$

In children with proven pathologic GER, there is a slightly higher incidence of chest X-ray pathological findings (19.75\%) compared to children with normal $\mathrm{MII} / \mathrm{pH}$ values (15.78\%), but a statistical analysis using a chi-squared test showed no statistically significant differences $(\chi 2=0.1571 ; p=0.692)$ : there was no significant difference in the proportion of children with pathological finding of chest X-ray between groups of children with pathologic GER compared to children with normal MII/pH values. This is also confirmed by the phi-coefficient of correlation that is low and not significant $(\Phi=0.04 ; p=0.692)$.

However, when only children with pathologic findings of chest $\mathrm{X}$-ray are observed, the proportion of children with pathologic GER is significantly higher in comparison to children with normal $\mathrm{MII} / \mathrm{pH}$ values. Using a chi-squared test on a single sample $\chi 2=8.9$; $p<0.01$ is obtained, where the authors are aware of the limited range of this result due to a small number of participants. Therefore, there is an indication of a greater presence of gastroesophageal reflux in children with endobronchitis or peribronchitis, i.e. in children who have pneumonia.

In a group of 100 children treated for chronic respiratory symptoms, 7 children have radiologically confirmed pneumonia and there is a pathological finding of multichannel intraluminal impedance, meaning that out of 100 children, $7 \%$ of children have aspiration pneumonia.

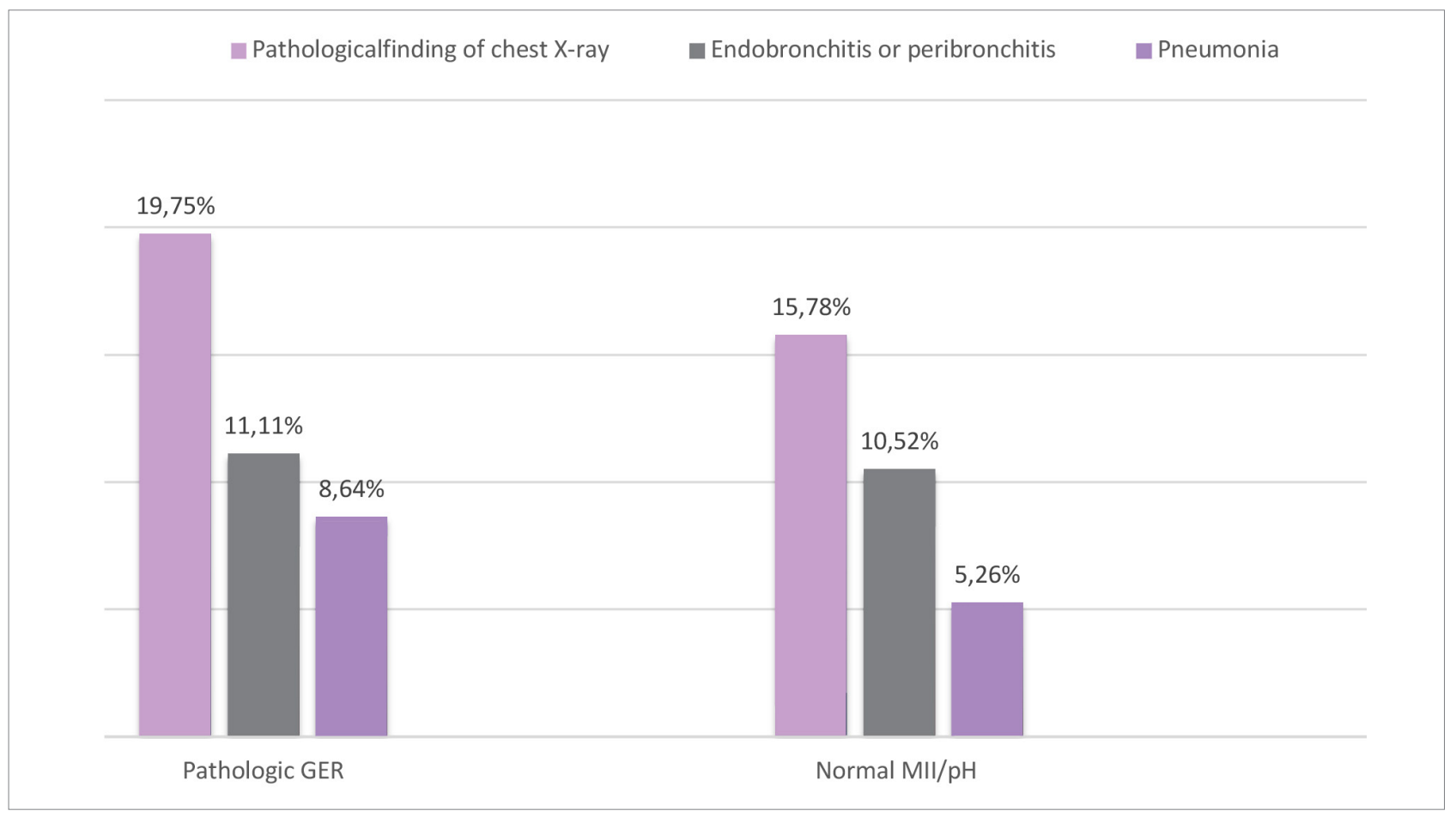

Graph 3. The incidence of pathological finding of chest X-ray in a group of children with pathologic GER 


\section{Discussion}

The published data connect a higher incidence of GER with smaller children $(1,2)$, a study published in 2000 (4) shows that the largest number of children with pathologic GER are infants. This study was conducted at the Department of Pulmonology and Allergology for Preschool and Schoolchildren, which does not normally treat children under the age of 3 . In this study, only 13 children were of the age of 3 years or younger, which affects the final average age in the group with pathologic gastroesophageal reflux. Children with aspiration changes in chest $\mathrm{X}$-ray associated with pathologic gastroesophageal reflux, have a lower age of 8.68 years, compared to the whole group and the group of children with only pathologic gastroesophageal reflux without aspiration changes in the chest X-ray. This may indicate that more severe reflux-induced changes are more pronounced in younger children.

In the study group of 100 children, pathologic GER was found in $81 \%$ of the children. A study conducted at the Zagreb Clinic for Children's Diseases and published in 2000 (4) indicated pathologic GER in 67.4\% of the children treated for chronic respiratory symptoms. The study was based on a 24-hour pH-metry without multichannel intraluminal impedance. In this study, children were treated with a combination of multichannel intraluminal impedance with $\mathrm{pH}$-metry which is a more sensitive method and higher results are explained by greater sensitivity of the method.

Aspiration pneumonia is more commonly described among children with risk factors for GER (5) such as psychomotor retardation, neuromuscular disorders, anatomic anomalies in the mouth area. The research group included children without risk factors. The obtained research results show that aspiration pneumonia is often present (8.64\%) in children with GER who do not have associated risk factors for aspiration. Statistical analysis showed that there was no significant difference in the proportion of children with pathologic findings of chest X-ray between the groups with pathologic GER and normal MII/pH values. This is not in accordance with our expectations, and the reason for such a result can be found in the participants' particularity since they are children who all have certain respiratory problems. Children with radiologically proven pneumonia and without proven gastroesophageal reflux, should undergo further tests such as immune or bronchology tests to exclude the cause of pneumonia.

In a group of 100 children treated for chronic respiratory symptoms, 7 children had radiologically detected pneumonia and there was a pathological finding of multichannel intraluminal impedance, meaning that out of 100 children, $7 \%$ had aspiration pneumonia. Studies on children with proven recurrent or persistent pneumonia have shown that aspiration causes pneumonia in $5 \%$ to $29 \%(14,15,16)$. In the abovementioned studies, only children with pneumonia symptoms were diagnosed while in the study group for the purpose of this work children with a wider range of chronic respiratory symptoms were included. Ghezzi and his associates, based on a twoyear retrospective study, have shown that children with frequent reflux episodes have increased risk of repeated respiratory infections (17). Rybak and his associates have demonstrated the correlation between acid reflux with chronic pulmonary symptoms (18), which Borelli explains in his study where he demonstrated the correlation between aspirated gastric contents in the respiratory system and respiratory symptoms resulting from it (19). The results of this study suggest that there is a significantly more frequent pathologic GER finding in children with pathologic findings of chest X-ray, but since this is a small number of participants, the findings should be checked on a larger sample. Aspiration pneumonia is more common in children with chronic respiratory symptoms (7\%) even when there are no symptoms typical for pneumonia such as febrility, cough, difficulty breathing and auscultation pathology. This is extremely important because the use of appropriate antireflux therapy such as antireflux measures and medication therapy with proton pump inhibitors can lead to treating inflammatory changes, prevention of disease progression, and termination of respiratory symptoms.

The weakness of research primarily refers to the absence of children under the age of 3 in the group of participants, meaning that the given age group is not adequately represented in the results of the study. Further research could analyse, as an important information, the frequency of aspiration pneumonia depending on the age group of children to see how much age and development of the respiratory system is essential for the development of pneumonia 
in GER. Also in this study, reflux height, i.e. the height to which the gastric contents are raised, was not analysed, and in further research it would be good to determine reflux height and the relationship between the height and type of reflux with radiological changes in the lungs.

\section{Conclusion}

Among children with chronic respiratory symptoms without any risk factors favoring the aspiration of the gastric contents, there were 7 children, i.e. $7 \%$ of patients with aspiration pneumonia caused by gastroesophageal reflux. There was no significant difference in the proportion of children with pathological findings of the chest $X$-ray between children with reflux and those without it. In children with pathological findings of chest X-ray, the proportion of children with gastroesophageal reflux is significantly higher in comparison to children with normal MII/pH values.

The obtained results indicate frequent presence of aspiration pneumonia in children with chronic respiratory symptoms, which confirms the need for active testing for gastroesophageal reflux in patients with respiratory symptoms and for the purpose of conducting adequate reflux treatment and pneumonia prevention.

\section{References}

1. Grgurić J. Gastroezofagealni refluks. Pediatr Croat. 2000;44(1):55-60. Croatian.

2. Peršić $M$, Tješić-Drinković $D$, Čohar $B$, Dujšin $M$, HegedušJungvirth $\mathrm{M}$, Jelić $\mathrm{N}$, et al. Postupnik (algoritam) za dijagnozu i liječenje patološkog gastroezofagealnogrefluksa u djece (preporuke Hrvatskog društva za dječju gastroenterologiju, hepatologiju i prehranu). Pediatr Croat. 2004;48(4):211-8. Croatian.

3. Bašić Marković N, Marković R, Diminić-Lisica I, Radošević Quadranti N. Gastroezofagealna refluksna bolest - bolest s mnogo lica. Acta Med Croatica. 2015;69:279-85. Croatian.

4. Čepin-Bogović J, Kolaček S, Grgurić Z, Zakanj Z, LokarKolbas R, Ivković-Jureković I, et al. Patološki gastroe- zofagealni refluks i pridružene respiratorne bolesti. Pediatr Croat. 2000;44(1):17-21. Croatian.

5. Rožmanić V, Ahel V, Banac S. Gastroezofagealni refluks u djece $s$ kroničnim bolestima dišnih puteva. Pediatr Croat. 2001;45(1):99-105. Croatian.

6. Colombo JL, Thomas HM. Aspiration syndromes. In: Taussig LM, Landaui LI, ed. Pediatric respiratory medicine, 2nd edition. Philadelphia: Mosby Elsevier; 2008.

7. Pavić I, Vela Ljubić J, Hojsak I. Laringofaringealni refluks kao uzrok respiratornih simptoma. Pediatr Croat. 2015;59:239-42. Croatian.

8. Wolfson BJ, Allen JL, Pantich HB, Karmazin N. Lipid aspiration pneumonia due to gastroesophageal reflux. A complication of nasogastric lipid feedings. Pediatr Radiol. 1989;19(8): 545-7.

9. Sifrim D, Fornari F. Esophageal impedance - $\mathrm{pH}$ monitoring. Dig Liv Dis. 2008;40:161-6.

10. Wenzl TG, Benninga MA, Loots CM, Salvatore $S$, Vandenplas Y; ESPGHAN EURO-PIG Working Group. Indications, methodology and interpretation of combined esophageal impedance-pH monitoring in children: ESPGHAN EURO-PIG standard protocol. ] Pediatr Gastroenterol Nutr. 2012;55(2):230-4.

11. Boesch RP, Wood RE. Aspiration. U: Wilmott RW, Boat TF, Bush A, Chernick V, Deterding RR, Ratjen F, ur. Kendig and Chernick's Disorders of the Respiratory Tract in Children, 8th Edition. Philadelphia: Mosby Elsevier; 2012.

12. Abu-Hasan M, Elmallah M, Neal D, Brookes J. Salivary amylase level in bronchoalveolar fluid as a marker of chronic pulmonary aspiration in children. Pediatr Allergy Immunol Pulmonol. 2014;27(3):115-9.

13. Vrankić D. Zadaci medicinske sestre u postavljanju i zbrinjavanju jednokratnih sondi za mjerenje ezofagealne multikanalneintraluminalneimpedance sa $\mathrm{pH}$ metrijom. U: Zbornik radova za medicinske sestre, Hrvatska proljetna pedijarijska škola, XXXI. Split, 2014. Croatian.

14. Kumar M, Biswal N, Bhuvaneswari V, Srinivasan S. Persistent pneumonia: underlying cause and outcome. Indian J Pediatr. 2009;76(12):1223-6.

15. Hoving MF, Brand PL. Causes of recurrent pneumonia in children in a general hospital. J Paediatr Child Health. 2013;49(3):208-12.

16. Owajed AF, Campbell DM, Wang EE. Underlying causes of recurrent pneumonia in children. Arch Pediatr Adolesc Med. 2000;154(2):190-4.

17. Ghezzi M, Silvestri $M$, Guida $E$, Pistorio A, Sacco 0 , Mattioli G, et al. Acid and weakly acid gastroesophageal refluxes and type of respiratory symptoms in children. Res Med. 2011;105(7):972-8.

18. Rybakk A, Pesce M, Thapar N, Borelli O. Gastro-Esophageal Reflux in Children. Int J Mol Sci. 2017;18(8):1671.

19. Borrelli O, Marabotto C, Mancini V, Aloi M, Macri F, Falconieri $\mathrm{P}$, et al. Role of gastroesophageal reflux in children with unexplained chronic cough. J Pediatr Gastroenterol Nutr. 2011;53(3):287-92. 


\section{POVEZANOST GASTROEZOFAGEALNOG REFLUKSA I UPALE PLUĆA KOD DJECE}

\section{Sažetak}

Uvod. Gastroezofagealni refluks jest povrat želučanog sadržaja u gornje dijelove probavnog trakta, a često dolazi do ulaska sadržaja u dišni sustav, pri čemu nastaju kronični respiratorni simptomi i oboljenja. Posebice se izdvaja aspiracijska upala pluća uzrokovana gastroezofagealnim refluksom. Gastroezofagealni refluks dijagnosticira se multikanalnom intraluminalnom impedancijom s pH-metrijom, a upala pluća dijagnosticira se radiološki. Analizom nalaza pacijentu se postavlja dijagnoza aspiracijske upale pluća.

Cilj. U djece bez rizičnih faktora koja se obrađuju zbog kroničnih respiratornih simptoma utvrditi povezanost gastroezofagealnog refluksa, dijagnosticiranog multikanalnom intraluminalnom impedancijom, s radiološkim nalazom upale pluća.

Metode. Studiju je provela medicinska sestra početkom 2017. godine na Odjelu za pulmologiju i alergologiju predškolske i školske dobi Dječje bolnice Srebrnjak na uzorku od 100 djece zaprimljene zbog kroničnih respiratornih simptoma, u kojih je učinjena multikanalna intraluminalna impedancija $\mathrm{s} \mathrm{pH}$-metrijom radi dokazivanja gastroezofagealnog refluksa. U navedene djece učinjen je i RTG pluća.

Rezultati. Patološki gastroezofagealni refluks očitan je kod 81 djece (81 \%), uredan RTG imalo je 81 dijete $(81 \%)$, a 19 djece (19 \%) imalo je patološki nalaz RTG-a, od toga upalu pluća osmero djece (42,1%).

Rasprava. Učinjenim istraživanjem u skupini od 100 djece s kroničnim respiratornim simptomima bez rizičnih čimbenika koji bi pogodovali aspiraciji želučanog sadržaja izolirano je sedmero djece s aspiracijskom upalom pluća uzrokovanom gastroezofagealnim refluksom.

Zaključak. Dobiveni rezultati pokazuju znatnu prisutnost aspiracijske upale pluća među djecom s kroničnim respiratornim simptomima, što potvrđuje potrebu aktivnog traženja gastroezofagealnog refluksa kod bolesnika s respiratornim simptomima, u svrhu provođenja adekvatnog liječenja refluksa i suzbijanja prisutne upale pluća.

Ključne riječi: gastroezofagealni refluks, aspiracijska upala pluća, impedancija 